\title{
Indonesia-China Strategic Partnership Transformation: Building Cooperation, Synergy, and Solidarity
}

\author{
Djauhari Oratmangun
}

Only a few months after Chairman Mao solemnly proclaimed the founding of the People's Republic of China atop the Gate of Heavenly Peace, famously known as Tiananmen Gate, on Saturday, October 1, 1949, Indonesia officially opened diplomatic relations with China on April 13, 1950, as political recognition and a gesture of friendship of both countries. However, the root of friendship between Indonesia and China can be traced back nearly a millennium when a Buddhist monk from China came to Nusantara in the fourteenth century when the great Admiral Zheng He, sent by the third Ming Emperor of China, led a diplomatic mission and visited Nusantara. ${ }^{1}$

Under the Presidency of Sukarno, Indonesia was among the first countries to establish political relations with China in 1950 and enjoyed close relations with the Beijing. The relations of both countries have become more profound, broader, and more robust since the administration of Indonesian President Abdurrahman Wahid (19992001, President Megawati Soekarnoputri (200-2004), President Susilo Bambang Yudhoyono (2004-2009, 2009-2014), and President Joko Widodo (2014-2019, 2019-present). The bilateral relations of Indonesia and China were also strengthened by signing the Joint Declaration on Strategic Partnership on April 25, 2005, and Future Direction of Indonesia-China Comprehensive Strategic Partnership on October 2, 2013.

Between April 13, 2020, and April 12, 2021, Indonesia and China commemorated the 70th anniversary of diplomatic relations and five years of the establishment of a Comprehensive Strategic Partnership. Hence, the year 2020/2021 provided momentum as both countries' partnership entered a "Platinum Jubilee" year. The seventieth year of collaboration in the context of state relationships is not a short

\footnotetext{
${ }^{1}$ Nusantara is an Indonesian word that refers to the Indonesian archipelago (https://kbbi.kemdik bud.go.id/entri/nusantara).

D. Oratmangun $(\bowtie)$

Embassy of the Republic of Indonesia to the People's Republic of China, Beijing, China 
time. Many obstacles and challenges have arisen, but working together has been the key to overcoming them. As members of the G20, and large countries in Asia, despite differences in their socio-cultural and political systems, Indonesia and China have shown the world the importance of cooperation, synergy, and solidarity among nations.

\section{Mutual Trust}

During the past 70 years of diplomatic relations, a great deal has been accomplished in numerous sectors such as politics, economy, trade, socio-culture, and investment. Particularly today, in the middle of the COVID-19 pandemic, Indonesia and China's partnership has been elevated to an even higher level. This strong relationship, especially under the current administration of President Joko Widodo, is mainly driven by political outlook, mutual trust, respect, and understanding between one another. Both leaders consistently engage in communicative dialog based on a principle of non-interference, instead of confrontation, ahead of everything.

For Indonesia, the principles underlying its "independent and active" foreign policy, which were expounded first time by the first Vice President of the Republic of Indonesia, Muhammad Hatta, on September 2, 1948, have been the foundation for establishing relations with other countries, including China. The policy, designed to serve the national interest and achieve world peace, is adaptable and has survived global changes, answering challenges and continuously contributing to solving world problems by putting forth a win-win solution for all. Strategic concerns are a significant part for both governments-Jakarta and Beijing-in strengthening bilateral relations.

Indonesia, with its 270 million people, and China, with its 1.4 billion people, need to collaborate and cooperate, both regionally in ASEAN and the Asia Pacific as well as globally. This cooperation is based on market factors, geopolitics, and geostrategy in the region.

Immense communication channels between leaders and high-level officers of both countries have been built by exchanging visits, telephone conversations, and letters. The visit of the Minister of Foreign Affairs of Indonesia and the Minister of State-owned Enterprises of Indonesia to China last August 2020 was the first visit of high-level foreign officials to China during the pandemic and showed mutual support in overcoming world crises. This support was strengthened by a subsequent visit to China by the Coordinating Minister of Maritime and Investment Affairs and the Minister of Health of Indonesia in October 2020. On the other side, China's Minister of Defense visited Indonesia in October 2020, and the State Councilor/Minister of Foreign Affairs of China also visited Indonesia in early 2021. These forms of communicative approaches have consolidated the foundation of the Indonesia-China strategic partnership in all areas of cooperation. 


\section{Trade and Investment Partners}

The partnership between Indonesia and China has transformed significantly and is developing very fast from the government-to-government level to people-to-people contact through cooperation in bilateral trade, investment, socio-cultural exchange, and tourism.

On the issue of trade, amid the COVID-19 pandemic that struck the entire world in 2020, Indonesia and China took trade cooperation to a higher level, with China remaining the leading trading partner of Indonesia. In 2020, the total trade volume of Indonesia and China reached USD 78.5 billion. From January to December 2020, the total export value of Indonesia to China reached USD 37.4 billion, an increase of 10.10 percent compared to the same period in 2019. This resulted in Indonesia moving to fourth, from fifth in 2019, among the largest exporters to China among ASEAN countries.

However, the total import value of goods from Indonesia to China in the period of January-December 2020 reached USD 41 billion, a decrease of $10.13 \%$ compared to the same period in 2019. In this period, Indonesia was able to balance its trade deficit with China of $68.96 \%$, with a deficit of USD 3.6 billion, compared to the same period in 2019, which saw a deficit of USD 11.7 billion.

In the investment sector, China's investment in Indonesia has increased steadily since 2016. For the last three years, China has been the second largest foreign investor in Indonesia. From January to December 2019, China's investment was valued at USD 4.7 billion, up $95.6 \%$ compared to investment in 2018. In this period, amid the challenges of the COVID-19 pandemic, China remained the second largest foreign investor in Indonesia after Singapore, with total investment value of USD 4.8 billion, up to $2.1 \%$ from the same period in 2019, while Hong Kong was the third biggest foreign investor in Indonesia, valued at USD 3.5 billion, an increase of $20.7 \%$ yearon-year.

In terms of investment in connectivity projects, the Jakarta-Bandung highspeed railway, a National Strategic Project for Indonesia, is a landmark project of Indonesia-China infrastructure cooperation as well as a flagship project of the Comprehensive Strategic Partnership of both countries. Indonesia is also the only country that has succeeded in synergizing the Chinese's Belt and Road Initiative (BRI) with Indonesia's Global Maritime Fulcrum (GMF) through the signing of Memorandum of Understanding on Jointly Promoting Cooperation within the Framework of the Global Maritime Fulcrum Vision and the Silk Road Economic Belt and the twenty-first-Century Maritime Silk Road Initiative in 2018. Under the framework of the BRI and GMF, four economic corridors have been developed in Indonesia, namely: North Sumatra, which is being developed as an "Economic and Business Hub for ASEAN"; North Kalimantan as an "Energy and Mineral Hub"; Bali as a "Hightech and Creative Economy Hub"; and North Sulawesi as a "Pacific Rim Economic Hub". Areas of cooperation include the development of technoparks, industrial parks, waste treatment projects, power plants, e-commerce, transportation, ports, special 
economic zones, 5G, sister ports, and fisheries. Specific projects include the JakartaBandung high-speed railway project; center of technology digital development in Turtle Island of Bali (Pulau Kura-Kura Bali); Karawang and Tangerang Industrial Park; Kuala Tanjung Port; Car Industrial Park; Morowali Industrial Park; and many more.

In addition to the synergy between the BRI and GMF, both Indonesia and China are the signatories to the Regional Comprehensive Economic Partnership (RCEP) Agreement. The agreement will undoubtedly speed up domestic and global economic recovery, health cooperation in the field of medicines and vaccines, green cooperation, and sustainable development with a spirit of inclusivity, openness, transparency, and multilateralism.

In the tourism sector and people-to-people contact, Indonesia has become the fourth largest tourist destination for Chinese tourists among ASEAN countries. Meanwhile, China is the second largest source of overseas tourists in Indonesia, with 2.1 million visits in 2019. With the hope that the COVID-19 pandemic will be over soon, Indonesia is preparing to welcome the Chinese tourist to work from Bali and the "Ten New Balis", namely Lombok Mandalika, Borobudur in Central Java, Lake Toba in North Sumatra, Tanjung Lesung in Banten, The Thousand Island in Jakarta, Tanjung Kelayang Beach in Bangka Belitung Islands, Mount Bromo in East Java, Labuan Bajo in East Nusa Tenggara, Wakatobi in South Sulawesi, and Morotai Island in North Maluku.

\section{Digital Economy}

The COVID-19 pandemic has brought tremendous changes and transformed many aspects of the current business arena. On one hand, the pandemic has devastated the global economy, with many countries still struggling to recover. On the other hand, the pandemic accelerated the digital adoption rate within society. People have been forced to do everything from online shopping, and online learning to online consulting, which eventually will become a habit. Moreover, the pandemic catapulted the digital transformation to the top of the priority list for practically every business and industry in the world. Operating business remotely online has become an unavoidable new normal. Since everything is connected, digital media has taken a significant part in promoting trade and investment. As a response to the crisis and the move toward the new normal where working from home is expected, the need for digital infrastructure is extremely essential and timely. Hence, unanimously acknowledging that the pandemic has dramatically accelerated the pace of digital transformation is truly an essential business requirement, as it has become what people around the globe are in need of today.

In this sense, to keep up with trends in technology and digitalization and encourage digital literacy in Indonesia, the current Minister of Education and Culture of Indonesia, who has established one unicorn in Indonesia, has suggested coding and programming be compulsory in education curricula, stating that the combination of 
these subjects is critical and a worthy investment for Indonesian human capital for the economy of the future.

In Indonesia, over 530,000 schools have closed amid the pandemic, affecting 68 million students from pre-primary through tertiary levels, making the need for effective Education Technology (EdTech) extremely urgent. The situation is forcing a very fast and broad increase in the country's use of EdTech, which is expected to have lasting effects on the market. Responding to this issue, Indonesia, under the administration of President Joko Widodo, has urged for a more robust digital transformation in education and distance learning in particular. The Indonesian government had allocated a whopping IDR 1.9 trillion or around USD 128.4 million for cellular data subsidies by cellular operators for students and teachers and another IDR 7.21 trillion or around USD 510 million in subsidies to provide free mobile Internet access for students across Indonesia. The number will also be increased accordingly to meet the need for the whole country's online classes.

However, digital transformation was a line item on many business agendas long before COVID-19 came along. In this regard, Indonesia has a great deal of potential in digitalization. Indonesia now has five unicorns and one decacorn, and 197 million Internet users as of 2020, with penetration hitting $74 \%$, up to $8.9 \%$ from last year. It also has high smartphone penetration, a young Internet-savvy population, and a growing middle-class.

Total e-commerce transactions in 2020 were valued at USD 44 billion and accounted for $72 \%$ of the entire Indonesian digital economy, an increase of $44 \%$ compared to 2019, valued at USD 21 billion. Along with the growing ecosystem, this figure is expected to reach USD 124 billion in 2025. According to e-Conomy SEA 2020 report by Google, Temasek, Bain and Company, Indonesia's digital consumer base surged $37 \%$ during the pandemic. This number is predicted to grow more in the coming year considering Indonesia's economic growth is supported by domestic consumption, and more retailers and consumers are being forced to explore e-commerce options. Before the COVID-19 pandemic, online travel transactions reached USD 10 billion in 2019. In terms of online payment, it is predicted that there will be more and more collaboration between e-commerce platforms with the e-wallet platform, which number has been rising since 2019.

In the financial sector, excellent connectivity opens more immense opportunities in the financial technology market and increases banking penetration. Indonesia is the world's tenth largest economy, but Indonesia also has the fourth largest unbanked population in the world. The change in people's behavior adapting to the new normal brought by the COVID-19 pandemic makes everything, including the banking sector and business, go digital. Currently, Indonesia is on its way to becoming a cashless society. The development of digital financing is growing significantly with the increase of e-wallet top-ups, mobile banking, and e-commerce transactions. Hence, despite the COVID-19 pandemic and global uncertainties today, Indonesia is home to 322 fintech (financial technology) companies.

The Indonesian government is now working on the telecommunication infrastructure to close the technology gap, including connecting 9,113 villages with 4G networks by 2022. In 2019, Indonesia launched the Palapa Ring Project in Tanimbar. 
The project aims to provide access to $4 \mathrm{G}$ Internet service to more than 500 regencies across the country with features more than $35,000 \mathrm{~km}$ (21,747 miles) of land and sea cables, stretching from the westernmost city in Indonesia, Sabang, to the easternmost town, Merauke, from the northernmost island Mianagas to the southernmost island, Rote. For the economic sector, the improvement in Internet connectivity will significantly impact industries across the countries and encourage economic development. However, it is also essential to mitigate the risk and challenges that arise in the digital era, namely cybercrime and data security.

To further support the development of information and communication technology (ICT) in 2021, President Jokowi Widodo announced a budget of IDR 30.5 trillion (around USD 2 billion), which will target accelerating digital government transformation, ensuring effective and efficient public services, particularly in the education, health, and government sectors; consolidating and optimizing shared infrastructure and services; and ensuring public participation in priority development areas; and promoting equality with other Internet access in approximately 4,000 villages and sub-districts in 3T (frontier, outermost, and underdeveloped) regions.

Indonesia is still in the early stages of building a digital economy. Nonetheless, it has a solid foundation. Looking back from a decade ago, e-commerce and ride-hailing services have become the industrial locomotive to expand digital-savvy coverage in Indonesia. Since then, a new digital business model has become easier to accept. In 2025, Indonesia's digital economy is projected at USD 130 billion which makes Indonesia the most significant economic digital player in ASEAN. The number contributes $22 \%$ of Indonesia's gross domestic income in 2020. Indonesia is also the regional hub for investment by venture capitalists, including several big investors from China, who are already investing in Indonesia, including Alibaba Ant Financial, Baidu, Tencent, and Meituan.

As the second largest digital economy in the world and the home of 162 unicorns, China's digital economy is predicted to reach USD 4.2 trillion in 2025. Given its eye for the digital sector, China has launched a massive Digital Maritime Silk Road project that aims to develop digital connectivity and infrastructure in the region. One of the factors that has supported China's economy in the middle of COVID-19 pandemic pressure is China's development in the digital economy sector.

In the development of the digital economy, Indonesia and China have established several areas of cooperation, including the establishment of the Turtle Island project (Pulau Kura-Kura Bali) under the cooperation of Bandung Institute and Tsinghua University as a center for IT R\&D, collaboration in coding education, and training at the Wekode School, launching of InaMall, virtual payment, IT education, vocational training, building e-commerce, fintech, and digital infrastructure.

To boost cooperation in the area of e-commerce, fintech, and digital infrastructure, as mentioned above, Indonesia has initiated cooperation with a number of outstanding companies in China, namely ByteDance, Meituan Inc, Alibaba Ant Financial, Jumore, JD.com, Baidu Inc, and Tencent Holdings Ltd. With the pandemic still present, it is essential to adapt the trend and emerge to be the winner within the crisis, and digitalization is the answer to the demand in order to survive. There are 
still plenty of opportunities for cooperation in this sector. Early this year, the Indonesian Minister of Trade launched IDNStore. This platform aims to support Indonesian SMEs to enter China's market and boost Indonesian exports to China.

\section{Future Cooperation}

In conclusion, reflecting on the 70 years of relations between Indonesia and China reveals big opportunities, particularly for Indonesia to further cooperate closely in partnership with China. The Strategic Partnership and Comprehensive Strategic Partnership have become an important instrument for this opportunity. In response to the issue of the COVID-19 pandemic, the Indonesian government established the COVID-19 Mitigation and the National Economic Recovery Committee on July 20, 2020, to replace the Task Force to accelerate the mitigation of the COVID-19 pandemic.

Furthermore, in 2020, in an effort to continuously attract and streamline business processes, President Joko Widodo's administration launched a new law called the "Omnibus Law" as a way to secure development and economic sustainability. The law mainly aims to revise several prevailing laws to settle fundamental issues that are curtailing business competitiveness in Indonesia. Through this law, investors now enjoy several benefits, such as more certainty in business, streamlined regulations, fiscal incentives, non-fiscal relief such as ease of licensing, more accessible investment locations or sites, and provisions by the government of certain infrastructure for investment locations or areas, and many more.

Looking into the digital potential of both countries, there is ample room for further cooperation and plenty of untapped opportunities ready to unfold. Indonesia and China are blessed with the same connectivity concepts with the GMF and the BRI, large populations, and great market volume. In this regard, both countries should walk together and work in tandem to mutually explore cooperation in the digital economy.

"Strategic, long term, and prosperous" are three keywords that represent the future bilateral ties of Indonesia and China. The only challenges ahead are common challenges in facing the pandemic and addressing the socio-economic recovery of the people of both nations. There are different perspectives on specific issues, but the key is to always keep communication open and to keep tension low should differences arise by mitigating public sentiment and voices that may affect smooth processes in strategical cooperation and ongoing joint efforts between our two countries. Therefore, as two great Asian nations with their own influence in ASEAN and the Asia Pacific region, Indonesia and China must synergize and coordinate their power to manage geopolitical, geostrategic, and security challenges in the Asia-Pacific region as well as to ensure global peace and security. 


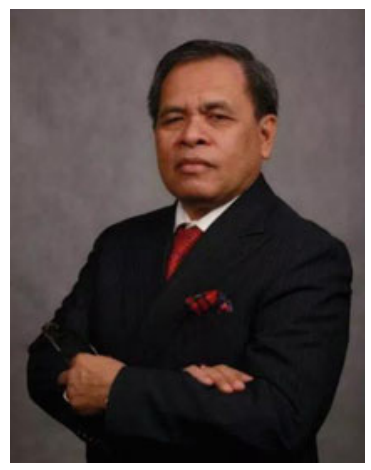

H.E. Mr. Djauhari Oratmangun is the ambassador of the Republic of Indonesia to the People's Republic of China and Mongolia. Before assuming his current position, he was the Senior Advisor on Strategic Issues to the Minister of Foreign Affairs of the Republic of Indonesia. He joined the Ministry of Foreign Affairs of the Republic of Indonesia in 1984. He had served as the Ambassador of the Republic of Indonesia to the Russian Federation and the Republic of Belarus (20122016), and as Deputy Minister for ASEAN Cooperation (20092011). Mr. Oratmangun has represented Indonesia in various regional and international conferences/forums, as speaker and head of delegation. He completed his degree in Economics at the University of Gadjah Mada in Yogyakarta, Indonesia, in 1981. $\mathrm{He}$ is married with three children.

Open Access This chapter is licensed under the terms of the Creative Commons AttributionNonCommercial-NoDerivatives 4.0 International License (http://creativecommons.org/licenses/bync-nd/4.0/), which permits any noncommercial use, sharing, distribution and reproduction in any medium or format, as long as you give appropriate credit to the original author(s) and the source, provide a link to the Creative Commons license and indicate if you modified the licensed material. You do not have permission under this license to share adapted material derived from this chapter or parts of it.

The images or other third party material in this chapter are included in the chapter's Creative Commons license, unless indicated otherwise in a credit line to the material. If material is not included in the chapter's Creative Commons license and your intended use is not permitted by statutory regulation or exceeds the permitted use, you will need to obtain permission directly from the copyright holder.

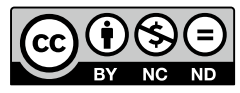

